\title{
TINJAUAN ATAS KESIAPAN KEMENTERIAN PEKERJAAN UMUM DAN PERUMAHAN RAKYAT TERKAIT KEIKUTSERTAAN INDONESIA DALAM GOVERNMENT PROCUREMENT AGREEMENT (GPA)
}

\author{
Aryo Hestuleksono \\ email: aryo.leksono@gmail.com
}

\begin{abstract}
Abstarct
Basically ratification of the GPA for Indonesia is the opening of the Indonesian market (market access) to the entrepreneur/companies from other countries, which means allowing entrepreneur/foreign companies to participate in the process of procurement of goods and services (PBJ) government in Indonesia. Similarly, the reverse with Indonesian companies. The existence of market acess makes the relation between national with international law. This is a reason of authors are interested to know further the relationship conformity with international law related to the readiness of the national Ministry of Public Works and Public Housing (PUPR) when Indonesia ratified the GPA views of the setting methods for selecting/auction in the construction sector in national legislation. The method used is a normative juridical research and the purpose of research to give recommendation to the Ministry PUPR particularly regarding setting methods for selecting the procurement of construction services when Indonesia ratified the GPA. If viewed from the side PBJ arrangements in the Government in the field of construction, especially regarding the purpose, principles and method of election of, the results showed that Ministry PUPR not ready when Indonesia ratified the GPA, because there is a difference between setting purpose PBJ contained in Perpres No. 54/2010 and its amendments as well as Permen PU No 07/2010 and amendments that more give protection to national companies, while GPA has the open principle. In addition there are differences about the method of selecting good views of the types/forms (nomenclature) and its meaning. So that when Indonesia will ratify the GPA, the Government and the Ministry PUPR in particular need to make adjustments to the "purpose" of regulation PBJ as contained in the Perpres/Permen PU with "purpose" contained in the GPA. Similarly, adjustments to the forms (nomenclature) and the meaning of the audition method.
\end{abstract}

Keywords:

Government Procurement Agreement. Ministry PUPR. Procurement of Government Goods/Services.

Market Access.

\begin{abstract}
Abstrak
Pada dasarnya ratifikasi terhadap GPA bagi Indonesia adalah pembukaan pasar Indonesia (market access) kepada pengusaha/perusahaan dari negara lain, yang berarti mengizinkan pengusaha/perusahaan asing dapat ikut pada pengadaan barang jasa (PBJ) pemerintah di Indonesia. Begitu pula hal sebaliknya dengan perusahaan Indonesia. Adanya keterbukaan pasar menjadikan adanya keterkaitan antara hukum nasional dengan internasional. Hal inilah yang menyebabkan penulis tertarik untuk meneliti lebih jauh kesesuaian hubungan hukum nasional dengan internasional terkait kesiapan Kementerian Pekerjaan Umum dan Perumahan Rakyat (PUPR) bila Indonesia melakukan ratifikasi GPA dilihat dari pengaturan metode pemilihan/pelelangan dalam bidang konstruksi pada peraturan hukum nasional. Metode penelitian yang digunakan adalah yuridis normatif dengan tujuan penelitian memberikan rekomendasi kepada Kementerian PUPR khususnya mengenai pengaturan metode pemilihan pada
\end{abstract}


pengadaan jasa konstruksi bila Indonesia meratifikasi GPA. Hasil penelitian menunjukan bila dilihat dari sisi pengaturan PBJ di lingkungan Pemerintah pada bidang konstruksi khususnya mengenai tujuan, prinsip dan metode pemilihan maka Kementerian PUPR belum siap apabila Indonesia melakukan ratifikasi GPA. Hal ini dikarenakan terdapat perbedaan tujuan pengaturan PBJ antara yang terdapat dalam Peraturan Presiden No. 54 Tahun 2010 dan perubahannya serta Peraturan Menteri Pekerjaan Umum No. 07 Tahun 2010 dan perubahannya yang sifatnya lebih memproteksi usaha nasional dengan GPA yang sifatnya lebih terbuka. Selain itu terdapat perbedaan bentuk metode pemilihan diantara keduanya baik dilihat dari jenis/bentuk (nomenklatur) dan maknanya. Sehingga apabila Indonesia akan melakukan ratifikasi GPA maka Pemerintah dan Kementerian PUPR pada khususnya perlu melakukan penyesuaian terhadap "tujuan" dari pengaturan PBJ sebagaimana yang terdapat dalam Perpres/Permen PU dengan "tujuan" yang terdapat dalam GPA. Begitu pula halnya penyesuaian terhadap bentuk-bentuk (nomenklatur) dan makna metode pemilihan.

Kata kunci:

Government Procurement Agreement. Kementerian PUPR. Pengadaan Barang/Jasa Pemerintah.

Pasar Terbuka.

\section{Pengantar}

Penyelenggaraan pemerintahan tidak dapat dilepaskan dari kegiatan pengadaan barang dan jasa. Hal ini dikarenakan melalui kegiatan ini lah sebagian besar kegiatan yang diperuntukkan bagi pelayanan publik dapat dijalankan, dari yang sifatnya pengadaan cukup sederhana seperti pengadaan alat tulis kantor sampai dengan pengadaan yang sifatnya besar seperti pengadaan dalam bidang infrastruktur (pembangunan bendungan, jalan, jembatan, perumahan dan lain sebagainya).

Sektor usaha jasa kontruksi di Indonesia memiliki peranan yang cukup penting dalam pertumbuhan ekonomi. Kondisi ini dapat terlihat dari Pendapatan Domestic Bruto (PDB) yang berjumlah Rp 2.5 triliyun di tahun 1980 melonjak menjadi Rp 34.4 triliun di tahun 1995 (Pertumbuhan senilai 15 kali lipat). ${ }^{1}$ .Sampai dengan saat ini usaha jasa konstruksi pun masih menjadi daya tarik bagi usaha bisnis di Indonesia, hal ini tidak terlepas dari program pemerintah yang memprioritaskan bidang infrastruktur menjadi program utama. Hal ini terlihat dari anggaran Kementerian Pekerjaan Umum dan Perumahan Rakyat (PURR) pada

\footnotetext{
1 Nazarkhan Yasin, Mengenal Kontrak Konstruksi di Indonesia, PT Gramedia Pustaka Pertama, Jakarta, 2006, hlm. 9.
} 
Tahun Anggaran 2016 senilai Rp 104,1 triliun yang merupakan kementerian dengan anggaran tertinggi dibandingkan kementerian lainnya. ${ }^{2}$

Besarnya dana yang diprioritaskan pada bidang infratrukstur tentunya perlu menjadi perhatian pemerintah dalam menerapkan prinsip-prinsip pengadaan barang dan jasa yang transparan dan akuntabel, karena sebagaian besar dana tersebut terserap melalui pengadaan barang dan jasa. KPK menyatakan bahwa perkara pengadaan barang dan jasa merupakan kasus yang paling dominan ${ }^{3}$, dari 468 kasus yang ditangani pada tahun 2015, 142 kasus korupsi berkaitan dengan pengadaan barang dan jasa. ${ }^{4}$

Kondisi ini menunjukan adanya kemungkinan bahwa usaha nasional belum mampu menyediakan barang/jasa dengan kualitas yang memadai/memenuhi syarat yang diinginkan dan juga belum mampu memberikan harga yang kompetitif. Apabila kegiatan pengadaan itu sendiri masih bermasalah maka akibatnya masyarakat lah yang dirugikan. Sehingga hal ini memberikan peluang bagi usaha asing untuk turut serta masuk ke dalam pengadaan barang dan jasa pemerintah bila pemerintah tidak memprioritaskan usaha nasional.

Indonesia perlu menyadari bahwa penerapan prinsip transparan dan akuntabel dapat dijadikan salah satu modal bagi Indonesia untuk turut serta dalam perdagangan internasional khususnya dalam pengadaan barang jasa pemerintah. Hal ini dikarenakan prinsip-prinsip tersebut merupakan beberapa prinsip umum yang diterapkan dalam Government Procurement Agreement (GPA).

2 Indra Antono, Ini 10 Kementerian dengan Anggaran Tertinggi Pada APBN Tahun 2016, http://nasional.kompas.com/read/2015/11/02/20094921/Ini.10.Kementerian.dengan. Anggaran.Tertinggi.dalam.APBN.2016, (terakhir diakses 2 Oktober 2016)

3 Yunita Amalia, KPK Sebut Korupsi Pengadaan Barang dan Jasa Paling Dominan, https://www.merdeka.com/peristiwa/kpk-sebut-korupsi-barang-dan-jasa-palingdominan.html. (terakhir diakses 2 Oktober 2016)

${ }^{4}$ Fauziah Mursid, KPK: 142 Kasus di KPK Berasal dari Pengadaan Barang, http://nasional.republika.co.id/berita/nasional/hukum/16/06/27/o9fkjg335-kpk-142-kasus-dikpk-berasal-dari-pengadaan-barang-dan-jasa.(terakhir diakses 2 Oktober 2016) 
Adapun prinsip-prinsip dalam GPA diantaranya adalah prinsip terbuka, adil dan transparan dalam proses pengadaan barang dan jasa di sektor pemerintah. ${ }^{5}$

Dalam setiap pertemuan pada forum WTO, Asia Pacific Economic Cooperation (APEC), dan Asian European Economic Meeting (ASEM), Indonesia selalu dihadapkan kepada permintaan atau desakan untuk melakukan ratifikasi terhadap Government Procurement Agreement (GPA). ${ }^{6}$ Dalam hal ini dinyatakan pula bahwa Indonesia akan meratifikasi GPA sekitar 5 (lima) sampai 7 (tujuh) tahun ke depan, ${ }^{7}$ artinya apabila hal ini dikemukakan pada tahun 2003 maka saat ini seharusnya Indonesia telah melakukan ratifikasi GPA.

Indonesia sendiri hingga saat ini hanya menjadi observer pada GPA dari 19 negara yang telah menjadi anggota. ${ }^{8}$ Hal ini sesuai dengan Undang-Undang No 7 tahun 1994 tentang Pengesahan Agreement Establishing The World Trade Organization (Persetujuan Pembentukan Organisasi Perdagangan Dunia), di mana disebutkan dalam penjelasan Undang-Undang ini bahwa Indonesia belum ikut serta dalam Persetujuan Dagang Plurilateral yang menjadi Lampiran 4 Persetujuan Pembentukan Organisasi Perdagangan Dunia tersebut. GPA itu sendiri merupakan persetujuan plurilateral dalam perdagangan.

Keanggotaan GPA itu sediri dari tahun ke tahun terus meningkat yang kemungkinan besar dikarenakan pengadaan pemerintah rata-rata memberikan 15\% atau lebih GDP dari suatu negara, serta perjanjian WTO tentang pengadaan barang dan jasa pemerintah mencakup pembelian barang, jasa serta pekerjaan konstruksi yang nilainya mencapai U\$ 1.7 triliyun dalam setahun. ${ }^{9}$ Hal ini tentunya merupakan potensi/keuntungan yang besar apabila suatu negara

\footnotetext{
5 Agreement on Government Procurement, https://www.wto.org/english/tratop_e/gproc_e/ gp_gpa_e.htm.(terakhir diakses 2 Oktober 2016)

6 Kwik Kian Gie, Kebijakan Pengadaan Barang dan Jasa Instansi Pemerintah, 3, http://perpustakaan.bappenas.go.id/lontar/file?file=digital/20438-[_Konten_]-Konten C3229.pdf.(terakhir diakses 2 Oktober 2016)

7 Id.

8 Supra no 6.

9 Governtment Procurement Agreement, https://www.wto.org/english/thewto_e/20y_e/ gpa_brochure2015_e.pdf .(terakhir diakses 2 Oktober 2016)
} 
melakukan ratifikasi GPA dengan catatan sumber daya suatu negara tersebut telah memadai

Pada dasarnya ratifikasi terhadap GPA bagi Indonesia adalah pembukaan pasar Indonesia (market access) kepada pengusaha-pengusaha dari negara lain, yang berarti mengizinkan pengusaha asing ikut serta pada proses pengadaan barang jasa pemerintah Indonesia, baik di pusat maupun di daerah. ${ }^{10}$ Begitu pula halnya perusahaan Indonesia, dapat turut serta pada pengadaan barang dan jasa pemerintah di luar Indonesia.

Masuknya perusahaan asing untuk ikut serta dalam usaha nasional dan begitu pula sebaliknya bagi perusahaan Indonesia dapat dikatakan sebagai bentuk globalisasi dan liberasasi perdagangan. Liberalisasi perdagangan jasa pada prinsipnya merupakan salah satu langkah untuk memperluas akses pasar bagi penyedia jasa asing dengan mengurangi perlakuan diskriminatif dan menghilangkan hambatan-hambatan terhadap perusahaan asing tersebut. Indonesia sendiri sejak tahun 1980-an telah mulai meliberalisasikan dan menderegulasikan kebijakan dan investasi, di mana dalam periode 1986-1990 tidak kurang dari 20 paket kebijakan liberalisasi perdagangan dan investasi telah

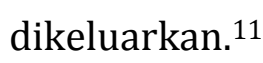

Pada dasarnya setiap negara memiliki peraturan yang mengatur mengenai pengadaan barang dan jasa (PBJ) pemerintah, begitu juga halnya dengan Indonesia. Pengaturan mengenai PBJ pemerintah di Indonesia diatur dalam Peraturan Presiden Nomor 54 Tahun 2010 Peraturan Presiden Nomor 54 Tahun 2010 Jo Peraturan Presiden 70 Tahun 2012 Jo Peraturan Presiden Nomor 04 Tahun 2015 Tentang Pengadaan Barang dan Jasa Pemerintah.

Salah satu hal yang diatur dalam Peraturan Presiden Nomor 54 Tahun 2010 dan peraturan perubahannya adalah mengenai metode pemilihan penyedia barang dan jasa. Dalam peraturan ini metode pemilihan dibagi menjadi metode

\footnotetext{
10 Kwik Kian Gie, supra catatan no 7 pada 3.

${ }^{11}$ Sjamsul Arifin, Dian Ediana Rae, Charles PR Joseph, Kerjasama Perdagangan Internasional Peluang dan Tantangan Bagi Indonesia, PT Elex Media Komputindo, Jakarta, 2007, hlm 9.
} 
pemilihan penyedia barang/jasa lainnya, metode pemilihan penyedia jasa konstruksi, metode pemilihan untuk penyedia barang/jasa lainnya yang merupakan hasil industri kreatif, inovatif dan budaya dalam negeri dan metode pemilihan penyedia jasa konsultansi.

Metode pemilihan penyedia barang/jasa lainnya dibagi lagi menjadi metode yang terdiri atas Pelelangan Umum dan Pelelangan Sederhana, Penunjukan Langsung, Pengadaan Langsung atau kontes dan sayembara, sedangkan metode pemilihan jasa konstruksi dibagi menjadi pelelangan umum, pelelangan terbatas, pemilihan langsung, penunjukan langsung dan pengadaan langsung. Adapun metode pemilihan penyedia jasa konsultasi dibagi menjadi seleksi umum, seleksi sederhana, penunjukan dan pengadaan langsung dan sayembara.

Bila melihat peraturan yang lebih khusus dalam bidang konstruksi maka terdapat Peraturan Menteri PU Nomor 07 Tahun 2011 Jo Peraturan Menteri PU Nomor 07 Tahun 2014 Jo Peraturan Menteri PUPR Nomor 31 Tahun 2015 Tentang Standar dan Pedoman Pengadaan Pekerjaan Konstruksi dan Jasa Konsultansi. Dalam peraturan tersebut diatur pula mengenai metode pemilihan, yang membedakan dengan Peraturan Presiden Nomor 54 Tahun 2010 dan peraturan perubahannya bahwa peraturan ini sifatnya lebih khusus yaitu diperuntukan untuk pengadaan jasa dalam bidang konstruksi di lingkungan Kementerian Pekerjaan Umum dan Perumahan Rakyat.

Banyaknya metode pemilihan dalam pengaturan di Indonesia tentunya perlu dicermati oleh Indonesia dan khususnya oleh Kementerian Pekerjaan Umum dan Perumahan Rakyat sebagai Kementerian dengan anggaran terbesar yang melakukan kegiatan pengadaan jasa konstruksi, ketika Indonesia akan melakukan ratifikasi GPA, karena bila dilihat secara sekilas maka terdapat perbedaan mengenai metode pemilihan penyedia barang atau jasa yang diatur dalam GPA dengan yang diatur dalam Peraturan Presiden Nomor 54 Tahun 2011 dan Peraturan Menteri Nomor 7 Tahun 2011. Dalam GPA metode pemilihan penyedia 
barang atau jasa yang disebut dengan prosedur pelelangan hanya dibagi menjadi tiga yaitu pelelangan terbuka, selektif dan terbatas.

Oleh karena itu berdasarkan latar belakang tersebut penulis akan melakukan kajian terhadap metode pemilihan penyedia barang dan jasa dalam bidang jasa konstruksi berdasarkan Peraturan Presiden Nomor 54 tahun 2010 dan Peraturan Menteri PU Nomor 7 Tahun 2011 dikaitkan dengan prosedur pelelangan pada GPA. Dalam hal ini apakah prosedur pelelangan dalam GPA telah mengakomodir metode pemilihan pada Peraturan Presiden Nomor 54 tahun 2010 dan Peraturan Menteri PU Nomor 07 Tahum 2011, yaitu bagaimana kesiapan Kementerian PUPR bila Indonesia melakukan ratifikasi GPA dilihat dari pengaturan metode pelelangan/pemilihan dalam bidang konstruksi pada peraturan hukum nasional? Tujuan penulisan ini adalah untuk memberikan rekomendasi kepada Kementerian Pekerjaan Umum dan Perumahan Rakyat khususnya mengenai pengaturan metode pemilihan pada pengadaan jasa konstruksi bila Indonesia meratifikasi GPA. Pengkajian dalam makalah ini akan menggunakan pendekatan yuridis normatif yang ditujukan untuk memahami penerapan norma-norma hukum terhadap fakta yang menitikberatkan fokus kajian pada asas-asas dan kaidah-kaidah hukum yang terdapat di berbagai ketentuan perundang-undangan yang berlaku maupun teori-teori hukum dalam berbagai literatur. ${ }^{12}$

\section{Tujuan Pengaturan Peraturan Presiden Nomor 54 Tahun 2010, Peraturan Menteri Pekerjaan Umum Nomor 7 Tahun 2011 dan GPA}

Dalam melakukan penelitian terhadap permasalahan di atas maka peneliti akan melakukan pembahasan atau kajian terlebih dahulu terhadap prinsip dan tujuan antara GPA dengan Peraturan Presiden Nomor 54 Tahun 2010 dan peraturan perubahannya serta Peraturan Menteri PU Nomor 07 Tahun 2011 dan

\footnotetext{
12 Soerjono Soekanto dan Sri Mamudji, Penelitian Hukum Normatif: Suatu Tinjauan Singkat, Rajawali Pers, Jakarta, 2012, hlm. 11.
} 
peraturan perubahannya. Hal ini ditujukan untuk mengetahui maksud dan tujuan dari ketiga pengaturan tersebut.

Pada dasarnya GPA merupakan persetujuan plurilateral dalam perdagangan internasional di mana persetujuan ini mengatur mengenai pengadaan barang dan jasa yang dilakukan oleh pemerintah bagi negara yang melakukan ratifikasi, artinya GPA ini ditujukan untuk negara yang melakukan ratifikasi.

Tujuan GPA itu sendiri sebagaimana yang terdapat dalam website WTO adalah $^{13}$ untuk memajukan transparansi, integritas dan persaingan dalam pasar pengadaan barang dan jasa pemerintah. Selain itu liberalisasi pasar pengadaan pemerintah memiliki potensi untuk menghasilkan manfaat baik dari segi efisiensi pengadaan dan kepentingan komersial. Sedangkan prinsip dari GPA sebagaimana yang terdapat dalam website WTO adalah terbuka, transparan dan nondiskriminatif/adil.

Kondisi ini sedikit berbeda dengan yang diatur dalam Peraturan Presiden Nomor 54 Tahun 2010 dan peraturan perubahannya serta Peraturan Menteri PU Nomor 07 Tahun 2011 dan peraturan perubahannya. Kedua peraturan tersebut merupakan peraturan yang mengatur mengenai pengadaan barang dan jasa (PBJ) di lingkungan pemerintah yang diperuntukkan bagi peserta dan panitia lelang.

Tujuan pengaturan PBJ di lingkungan pemerintah sebagaimana yang terdapat dalam Penjelasan Peraturan Presiden Nomor 54 Tahun 2010 yaitu:

a. meningkatkan iklim investasi yang kondusif, efisiensi belanja negara, dan percepatan pelaksanaan APBN/APBD.

b. meningkatkan keberpihakan terhadap industri nasional dan usaha kecil, serta menumbuhkan industri kreatif, inovasi, dan kemandirian bangsa dengan mengutamakan penggunaan industri strategis dalam negeri.

\footnotetext{
13 Supra no 6.
} 
c. meningkatkan ownership Pemerintah Daerah terhadap proyek/kegiatan yang pelaksanaannya dilakukan melalui skema pembiayaan bersama (cofinancing) antara Pemerintah Pusat dan Pemerintah Daerah.

Sedangkan tujuan pengaturan PBJ di lingkungan Pemerintah yang terdapat dalam Peraturan Menteri PU Nomor 07 tahun 2011 terdapat dalam pasal 2 ayat 2, yaitu agar penyelenggaraan jasa konstruksi lebih operasional dan efektif.

Melihat uraian di atas maka dapat disimpulkan bahwa terdapat perbedaan tujuan antara yang terdapat dalam Peraturan Presiden Nomor 54 dan Peraturan Perubahannya dengan Peraturan Menteri PU Nomor 07 Tahun 2011 dengan Peraturan Perubahannya begitu pula halnya dengan yang terdapat pada GPA. Perbedaan tujuan yang paling mencolok adalah antara Peraturan Presiden Nomor 54 dan Peraturan Perubahannya dengan GPA di mana Peraturan Presiden lebih mengedepankan peningkatan keberpihakan terhadap industri nasional dan usaha kecil serta mengutamakan penggunaan industri strategis dalam negeri sedangkan tujuan dari GPA adalah memajukan persaingan dalam pasar pengadaan barang dan jasa pemerintah di pasar global.

Sedangkan bila berbicara mengenai tujuan yang tercantum dalam Peraturan Menteri PU Nomor 07 Tahun 2011, maka tujuan yang ada terlihat cukup sederhana dan berbeda jauh dengan tujuan yang terdapat dalam Peraturan Presiden Nomor 54 Tahun 2010 dan GPA namun dalam konsideran Permen tersebut disebutkan salah satunya adalah dengan mengingat Peraturan Presiden Nomor 54 Tahun 2010, artinya tujuan dalam Permen tersebut secara garis besar mengacu pada Peraturan Presiden Nomor 54 Tahun 2010 atau sifatnya mutatis mutandis.

Persamaan tujuan dari kedua peraturan tersebut dengan GPA adalah mengedepankan efesiensi dan meningkatkan iklim investasi. Dalam GPA tujuan peningkatan iklim invetasi tidaklah tersurat namun tersirat dalam kalimat memajukan persaingan dalam pasar pengadaan barang dan jasa pemerintah khususnya dalam pasar global. 


\section{Prinsip-prinsip Pengadaan Barang/Jasa Pemerintah sesuai dengan}

Peraturan Presiden Nomor 54 Tahun 2010, Peraturan Menteri Nomor 07 Tahun 2011 dan GPA.

Adapun prinsip-prinsip PBJ di lingkungan Pemerintah sebagaimana diatur dalam Peraturan Presiden Nomor 54 Tahun 2010 dan peraturan perubahannya, memiliki prinsip yaitu efektif, efesien, transparan, terbuka, bersaing, adil, tidak diskiriminatif dan akuntabel. Sedangkan dalam Peraturan Menteri PU Nomor 07 Tahun 2011 dan peraturan perubahannya memiliki prinsip yaitu para pihak yang terkait dalam pelaksanaan Pengadaan Barang/Jasa harus mematuhi ketentuan sebagai berikut, yaitu:

a. tidak saling mempengaruhi baik langsung maupun tidak langsung yang berakibat terjadinya persaingan tidak sehat.

b. menghindari dan mencegah terjadinya pertentangan kepentingan para pihak yang terkait, baik secara langsung maupun tidak langsung dalam proses Pengadaan Barang/Jasa

c. menghindari dan mencegah penyalahgunaan wewenang dan/atau kolusi dengan tujuan untuk keuntungan pribadi, golongan atau pihak lain yangsecara langsung atau tidak langsung merugikan negara.

d. tidak menerima, tidak menawarkan atau tidak menjanjikan untuk memberi atau menerima hadiah, imbalan, komisi, rabat dan berupa apa saja dari atau kepada siapapun yang diketahui atau patut diduga berkaitan dengan Pengadaan Barang/Jasa

Melihat uraian di atas maka prinsip-prinsip pengadaan barang dan jasa yang terdapat pada dua peraturan di atas dengan GPA secara garis besar memiliki kesamaan dengan prinsip GPA yaitu ${ }^{14}$ dengan mengedepankan prinsip transparansi, terbuka dan tidak diskriminatif meskipun memang prinsip yang terdapat dalam Peraturan Presiden Nomor 54 Tahun 2010 dan peraturan perubahannya mengedepankan pula prinsip efektif, efesien dan akuntabel.

14 Id. 


\section{Metode Pemilihan/Pelelangan pada Peraturan Presiden Nomor 54 Tahun 2010, Peraturan Menteri Nomor 07 Tahun 2011 dan GPA.}

Hal lainnya yang perlu diperhatikan mengenai kesiapan Pemerintah khususnya Kementerian PUPR bila Indonesia meratifikasi GPA adalah terkait dengan pengaturan metode pelelangan/pemilihan yang terdapat dalam Peraturan Presiden Nomor 54 dan peraturan perubahannya, Peraturan Menteri PUPR dan Peraturan Perubahannya dengan GPA.

Secara garis besar tidak terdapat perbedaan yang signifikan mengenai jenis metode pemilihan/pelelangan antara yang terdapat dalam Peraturan Presiden Nomor 54 tahun 2010 dan peraturan perubahannya dengan Peraturan Menteri PU Nomor 7 Tahun 2011 dan peraturan perubahannya. Hal yang membedakan adalah dalam Peraturan Menteri PU Nomor 7 Tahun 2011 dan peraturan perubahannya tidak mengatur secara jelas mengenai metode pemilihan/pelelangan dengan cara penunjukan langung, pengadaan langsung dan sayembara, namun dalam prakteknya metode-metode tersebut adakalanya digunakan dalam bidang jasa konstruksi pada instansi pemerintah (Kementerian PUPR). Meskipun demikian hal ini bukan berarti tidak ada aturan yang mendasari dalam pelaksanaannya yang dilakukan Kementerian PUPR, hal ini dikarenakan konsideran Peraturan Menteri PU Nomor 7 Tahun 2011 dan peraturan perubahannya "mengingat berdasarkan Peraturan Presiden Nomor 54 Tahun 2010" sehingga yang menjadi dasar adalah Peraturan Presiden Nomor 54 Tahun 2010 karena sifatnya mutatis mutandis.

Bila dibandingkan dengan pengaturan pada GPA, GPA hanya membagi metode pemilihan/pelelangan menjadi 3 (tiga) jenis yaitu pelelangan umum, selektif dan terbatas. Persamaan yang ada dengan hukum nasional (Peraturan Presiden Nomor 54 Tahun 2010 dan Peraturan Menteri Nomor 7 Tahun 2011) adalah hanya terkait dengan pelelangan umum sedangkan mengenai pelelangan selektif dan terbatas memiliki pengertian yang berbeda sebagaimana yang diatur dalam hukum nasional. Dalam hukum nasional tidak diatur mengenai pelelangan selektif sebagaimana yang dimaksud dalam GPA, yang ada adalah metode seleksi 
umum dan sederhana yang ditujukan untuk pengadaan jasa konsultansi. Metode pelelangan terbatas dalam hukum nasional dengan GPA memiliki pengertian yang berbeda, namun jenis metode penunjukan langsung dapat dikategorikan kepada pelelangan terbatas di dalam pengaturan GPA. Sehingga yang tidak ada pengaturannya dalam GPA adalah mengenai pengadaan langsung dan sayembara.

Perbandingan Tujuan, Prinsip, Metode Pemilihan/Pelelangan yang terdapat pada Peraturan Presiden Nomor 54 Tahun 2010, Peraturan Menteri Nomor

\section{Tahun 2011 dan GPA.}

Bila diuraikan melalui matriks maka uraian di atas dapat disajikan sebagai berikut:

\begin{tabular}{|c|c|c|c|}
\hline No & $\begin{array}{c}\text { Peraturan Presiden } \\
\text { Nomor 54 Tahun } 2010 \\
\text { dan Peraturan } \\
\text { Perubahannya } \\
\end{array}$ & $\begin{array}{l}\text { Peraturan Menteri PU } \\
\text { Nomor } 7 \text { Tahun } 2011 \text { dan } \\
\text { peraturan perubahannya }\end{array}$ & GPA \\
\hline \multirow[t]{2}{*}{1} & Addresif & & \\
\hline & Peserta dan Panitia lelang & Peserta dan Panitia lelang & Negara \\
\hline \multirow[t]{4}{*}{2} & Tujuan & & \\
\hline & $\begin{array}{l}\text { Tujuan pengaturan PBJ } \\
\text { sebagaimana terdapat } \\
\text { dalam Penjelasan } \\
\text { Peraturan Presiden } \\
\text { Nomor } 54 \text { Tahun } 2010 \\
\text { yaitu: }\end{array}$ & $\begin{array}{l}\text { Tujuan Pengaturan PBJ } \\
\text { terdapat dalam pasal } 2 \text { ayat } 2 \text {, } \\
\text { yaitu agar: } \\
\text { penyelenggaraan jasa } \\
\text { konstruksi lebih operasional } \\
\text { dan efektif }\end{array}$ & $\begin{array}{l}\text { Tujuan GPA sebagaimana yang } \\
\text { terdapat dalam web site WTO adalah } \\
\text { untuk memajukan transparansi, } \\
\text { intergritas dan persaingan dalam } \\
\text { pasar pengadaan barang dan jasa } \\
\text { pemerintah. }\end{array}$ \\
\hline & $\begin{array}{l}\text { a. meningkatkan iklim } \\
\text { investasi yang } \\
\text { kondusif, efisiensi } \\
\text { belanja negara, dan } \\
\text { percepatan } \\
\text { pelaksanaan APBN/ } \\
\text { APBD. }\end{array}$ & & $\begin{array}{l}\text { Selain itu liberalisasi pasar } \\
\text { pengadaan pemerintah memiliki } \\
\text { potensi untuk menghasilkan } \\
\text { manfaat baik dari segi efisiensi } \\
\text { pengadaan dan kepentingan } \\
\text { komersial. }\end{array}$ \\
\hline & $\begin{array}{l}\text { b. Meningkatkan } \\
\text { keberpihakan terhadap } \\
\text { industri nasional dan } \\
\text { usaha kecil, serta } \\
\text { menumbuhkan } \\
\text { industri kreatif, } \\
\text { inovasi, dan } \\
\text { kemandirian } \\
\text { bangsadengan } \\
\text { mengutamakan } \\
\text { penggunaan industri } \\
\text { strategis dalam negeri. }\end{array}$ & & \\
\hline
\end{tabular}




\begin{tabular}{cccc}
\hline No & $\begin{array}{c}\text { Peraturan Presiden } \\
\text { Nomor 54 Tahun 2010 } \\
\text { dan Peraturan } \\
\text { Perubahannya }\end{array}$ & $\begin{array}{c}\text { Peraturan Menteri PU } \\
\text { Nomor 7 Tahun 2011 dan } \\
\text { peraturan perubahannya }\end{array}$ & GPA \\
\hline
\end{tabular}

c. meningkatkan

ownership Pemerintah

Daerah terhadap

proyek/ kegiatan yang

pelaksanaannya

dilakukan melalui

skema pembiayaan

bersama (cofinancing)

antara Pemerintah

Pusat dan Pemerintah

Daerah

Pengadaan Barang/Jasa menerapkan prinsipprinsip efektif, efesien, transparan, terbuka, bersaing, adil/tidak diskriminatif, akuntabel
Para pihak yang terkait dalam pelaksanaan Pengadaan Barang/Jasa harus mematuhi ketentuan sebagai berikut yaitu

a. tidak saling mempengaruhi baik langsung maupun tidak langsung yang berakibat terjadinya persaingan tidak sehat.

b. menghindari dan mencegah terjadinya pertentangan kepentingan para pihak yang terkait, baik secara langsung maupun tidak langsung dalam proses Pengadaan Barang/Jasa

c. menghindari dan mencegah penyalahgunaan wewenang dan/atau kolusi dengan tujuan untuk keuntungan pribadi, golongan atau pihak lain yang secara langsung atau tidak langsung merugikan negara.

d. tidak menerima, tidak menawarkan atau tidak menjanjikan untuk memberi atau menerima hadiah, imbalan, komisi, rabat dan berupa apa saja dari atau kepada siapapun yang diketahui atau patut diduga berkaitan dengan Pengadaan Barang/Jasa.
Prinsip GPA sebagaimana yang terdapat dalam web site WTO adalah terbuka, transparan dan nondiskriminatif/adil 


\begin{tabular}{|c|c|c|c|}
\hline No & $\begin{array}{c}\text { Peraturan Presiden } \\
\text { Nomor 54 Tahun } 2010 \\
\text { dan Peraturan } \\
\text { Perubahannya }\end{array}$ & $\begin{array}{c}\text { Peraturan Menteri PU } \\
\text { Nomor } 7 \text { Tahun } 2011 \text { dan } \\
\text { peraturan perubahannya }\end{array}$ & GPA \\
\hline 4 & $\begin{array}{l}\text { Metode } \\
\text { pemilihan/pelelangan }\end{array}$ & & \\
\hline A & $\begin{array}{l}\text { Pelelangan Umum, } \\
\text { metode pemilihan } \\
\text { Penyedia } \\
\text { Barang/Pekerjaan } \\
\text { Konstruksi/Jasa Lainnya } \\
\text { untuk semua pekerjaan } \\
\text { yang dapat diikuti oleh } \\
\text { semua Penyedia } \\
\text { Barang/Pekerjaan } \\
\text { Konstruksi/Jasa Lainnya } \\
\text { yang memenuhi syarat }\end{array}$ & Pelelangan Umum & $\begin{array}{l}\text { Open tendering procedures are those } \\
\text { procedures under which all interested } \\
\text { suppliers may submit a tender. }\end{array}$ \\
\hline B & $\begin{array}{lr}\text { Pemilihan langsung, } \\
\begin{array}{lr}\text { Pemilihan } & \text { Langsung } \\
\text { adalah metode } & \text { pemilihan } \\
\text { Penyedia } & \text { Pekerjaan } \\
\text { Konstruksi } & \text { untuk } \\
\text { pekerjaan yang } & \text { bernilai } \\
\text { paling } & \text { tinggi } \\
\text { Rp5.000.000.000,00 (lima } \\
\text { miliar rupiah) }\end{array}\end{array}$ & Pemilihan Langsung & $\begin{array}{l}\text { Selective tendering procedures are } \\
\text { those procedures under which, } \\
\text { consistent with paragraph } 3 \text { of Article } \\
\text { X and other relevant provisions of this } \\
\text { Agreement, those suppliers invited to } \\
\text { do so by the entity may submit a } \\
\text { tender. } \\
\text { Article 10: } \\
\text { 1. Suppliers requesting to } \\
\text { participate in a particular } \\
\text { intended procurement shall be } \\
\text { permitted to submit a tender and } \\
\text { be considered, provided, in the } \\
\text { case of those not yet qualified, } \\
\text { there is sufficient time to complete } \\
\text { the qualification procedure under } \\
\text { Articles VIII and IX. The number of } \\
\text { additional suppliers permitted to } \\
\text { participate shall be limited only by } \\
\text { the efficient operation of the } \\
\text { procurement system. }\end{array}$ \\
\hline
\end{tabular}

c. Pelelangan Terbatas, Pelelangan Terbatas

metode pemilihan

Penyedia

Barang/Pekerjaan

Konstruksi dengan jumlah

Penyedia yang mampu

melaksanakan diyakini

terbatas dan untuk

pekerjaan yang kompleks.

Pekerjaan Kompleks

adalah pekerjaan yang

memerlukan teknologi

tinggi, mempunyai risiko

tinggi, menggunakan
Limited tendering procedures are those procedures where the entity contacts suppliers individually, only under the conditions specified in Article XV.

Article 15:

The provisions of Articles VII through XIV governing open and selective tendering procedures need not apply in the following conditions, provided that limited tendering is not used with a view to avoiding maximum possible competition or in a manner which would constitute a means of discrimination among suppliers of 


\begin{tabular}{ccc}
\hline No & Peraturan Presiden & Peraturan Menteri PU \\
Nomor 54 Tahun 2010 & Nomor 7 Tahun 2011 dan \\
dan Peraturan & peraturan perubahannya \\
Perubannya & & \\
& perannyan
\end{tabular}

peralatan yang didesain

khusus dan/atau

pekerjaan yang bernilai

diatas

Rp100.000.000.000,00

(seratus miliar rupiah)

other Parties or protection to

domestic producers or suppliers:

(a) in the absence of tenders in response to an open or selective tender, or when the tenders submitted have been collusive, or not in conformity with the essential requirements in the tender, or from suppliers who do not comply with the conditions for participation provided for in accordance with this Agreement, on condition, however, that the requirements of the initial tender are not substantially modified in the contract as awarded;

(b) when, for works of art or for reasons connected with protection of exclusive rights, such as patents or copyrights, or in the absence of competition for technical reasons, the products or services can be supplied only by a particular supplier and no reasonable alternative or substitute exists;

(C) in so far as is strictly necessary when, for reasons of extreme urgency brought about by events unforeseeable by the entity, the products or services could not be obtained in time by means of open or selective tendering procedures;

(d) for additional deliveries by the original supplier which are intended either as parts replacement for existing supplies, or installations, or as the extension of existing supplies, services, or installations where a change of supplier would compel the entity to procure equipment or services not meeting requirements of interchangeability with already existing equipment or services5;

(e) when an entity procures prototypes or a first product or service which are developed at its request in the course of, and for, a particular contract for research, experiment, study or original development. When such contracts have been fulfilled, subsequent 


\begin{tabular}{ccc}
\hline No & Peraturan Presiden \\
Nomor 54 Tahun 2010 & Peraturan Menteri PU \\
dan Peraturan & Nomor 7 Tahun 2011 dan \\
Perubahannya & peraturan perubahannya
\end{tabular}

GPA

procurements of products or services shall be subject to Articles VII through XIV6;

(f) when additional construction services which were not included in the initial contract but which were within the objectives of the original tender documentation have, through unforeseeable circumstances, become necessary to complete the construction services described therein, and the entity needs to award contracts for the additional construction services to the contractor carrying out the construction services concerned since the separation of the additional construction services from the initial contract would be difficult for technical or economic reasons and cause significant inconvenience to the entity. However, the total value of contracts awarded for the additional construction services may not exceed 50 per cent of the amount of the main contract;

(g) for new construction services consisting of the repetition of similar construction services which conform to a basic project for which an initial contract was awarded in accordance with Articles VII through XIV and for which the entity has indicated in the notice of intended procurement concerning the initial construction service, that limited tendering procedures might be used in awarding contracts for such new construction services;

(h)for products purchased commodity market; untuk produk yang dibeli di pasar komoditas;

(i) for purchases made under exceptionally advantageous conditions which only arise in the very short term. This provision is intended to cover unusual disposals by firms which are not normally suppliers, or disposal of assets of businesses in liquidation or receivership. It is not intended to 


\begin{tabular}{ccc}
\hline No & Peraturan Presiden \\
Nomor 54 Tahun 2010 & Peraturan Menteri PU \\
dan Peraturan & Nomor 7 Tahun 2011 dan \\
Perubahannya & peraturan perubahannya
\end{tabular}

cover routine purchases from regular suppliers;

(j) in the case of contracts awarded to the winner of a design contest provided that the contest has been organized in a manner which is consistent with the principles of this Agreement, notably as regards the publication, in the sense of Article IX, of an invitation to suitably qualified suppliers, to participate in such a contest which shall be judged by an independent jury with a view to design contracts being awarded to the winners.

2. Entities shall prepare a report in writing on each contract awarded under the provisions of paragraph 1. Each report shall contain the name of the procuring entity, value and kind of goods or services procured, country of origin, and a statement of the conditions in this Article which prevailed. This report shall remain with the entities concerned at the disposal of the government authorities responsible for the entity in order that it may be used if required under the procedures of Articles XVIII, XIX, XX and XXII.

d Penunjukan Langsung, Seleksi Umum

Metode pemilihan

Penyedia Barang/Jasa

dengan cara menunjuk langsung 1 (satu)

Penyedia Barang/Jasa.

e Pengadaan Langsung, Seleksi Sederhana

Pengadaan Barang/Jasa

langsung kepada Penyedia

Barang/Jasa, tanpa

melalui Pelelangan/

Seleksi/Penunjukan

Langsung

f Seleksi Umum,

Seleksi Umum adalah metode pemilihan

Volume $2 \bullet$ Nomor $2 \bullet 457 \bullet$ 


\begin{tabular}{|c|c|c|c|}
\hline No & $\begin{array}{c}\text { Peraturan Presiden } \\
\text { Nomor } 54 \text { Tahun } 2010 \\
\text { dan Peraturan } \\
\text { Perubahannya }\end{array}$ & $\begin{array}{c}\text { Peraturan Menteri PU } \\
\text { Nomor } 7 \text { Tahun } 2011 \text { dan } \\
\text { peraturan perubahannya }\end{array}$ & GPA \\
\hline & $\begin{array}{l}\text { Penyedia Jasa Konsultansi } \\
\text { untuk pekerjaan yang } \\
\text { dapat diikuti oleh semua } \\
\text { Penyedia Jasa Konsultansi } \\
\text { yang memenuhi syarat }\end{array}$ & & \\
\hline $\bar{G}$ & $\begin{array}{l}\text { Seleksi Sederhana } \\
\text { Seleksi Sederhana adalah } \\
\text { metode pemilihan } \\
\text { Penyedia Jasa Konsultansi } \\
\text { untuk Jasa Konsultansi } \\
\text { yang } \\
\text { bernilai paling tinggi } \\
\text { Rp200.000.000,00 (dua } \\
\text { ratus juta rupiah). }\end{array}$ & & \\
\hline & $\begin{array}{l}\text { Sayembara, } \\
\text { Sayembara adalah metode } \\
\text { pemilihan Penyedia Jasa } \\
\text { yang memperlombakan } \\
\text { gagasan orisinal, } \\
\text { kreatifitas dan inovasi } \\
\text { tertentu yang } \\
\text { harga/biayanya tidak } \\
\text { dapat ditetapkan } \\
\text { berdasarkan Harga } \\
\text { Satuan. }\end{array}$ & & \\
\hline
\end{tabular}

Setelah dilakukan pembahasan mengenai tujuan, prinsip dan metode pemilihan pada Peraturan Presiden Nomor 54 dan peraturan perubahannya, Peraturan Menteri PU Nomor 07 Tahun 2011 dan peraturan perubahannya serta GPA maka dapat diketahui bahwa bila melihat tujuan yang ada diantara Peraturan Presiden/Peraturan Menteri PU tersebut dengan GPA, terlihat bahwa Kementerin PUPR belum siap apabila Indonesia melakukan ratifikasi GPA. Hal ini dikarenakan tujuan dari pengaturan pengadaan barang dan jasa di lingkungan Pemerintah pada Peraturan Presiden/Peraturan Menteri PU tersebut lebih mengedepankan sifat proteksionisme terhadap industri/usaha nasional sedangkan GPA itu sendiri bersifat terbuka.

Sifat prokteksionime tersebut tercermin pula pada beberapa pasal dalam Peraturan Presiden/Peraturan Menteri 54 Tahun 2010 dan peraturan 
perubahannya seperti salah satunya pada pasal pasal 101 ayat 1 yang menyebutkan bahwa:

“ Pengadaan Barang/Jasa yang dilaksanakan melalui Pelelangan/ Seleksi internasional harus memberikan kesempatan seluas-luasnya kepada Penyedia Barang/Jasa nasional."

Dalam penjelasan ayat ini dijelaskan bahwa:

"Untuk Pengadaan Barang/Jasa internasional yang dilakukan di luar negeri melalui Pelelangan/Seleksi Internasional, dilakukan semaksimal mungkin mengikutsertakan Penyedia Barang/Jasa nasional."

Ketentuan dalam ayat 6 huruf a menyebutkan bahwa:

"Dalam Dokumen Pengadaan yang diikuti oleh Penyedia Barang/Jasa asing memuat hal-hal sebagai berikut:

a. adanya kerja sama antara Penyedia Barang/Jasa asing dengan industri dalam negeri, dalam hal diperlukan dan/atau dimungkinkan"

Adapun pasal-pasal lainnya yang menunjukan sikap proteksionime terhadap usaha nasional diantaranya adalah:

a. Pasal 96 ayat 5 di mana dalam pasal ini secara garis besar menyatakan bahwa dalam pengadaan barang/jasa diupayakan agar penyedia barang dan jasa dalam negeri bertindak sebagai penyedia barang/jasa utama sedangkan penyedia barang/jasa asing dapat berperan sebagai sub penyedia barang/jasa sesuai dengan kebutuhan.

b. Pasal 104 ayat 1 yang mengatur batasan-batasan minimal nilai untuk keikutsertaan perusahaan asing dalam pengadaan barang/jasa pemerintah di Indonesia.

c. Pasal 104 ayat 2 yang secara garis besar menyatakan bahwa perusahaan asing yang melaksanakan pengadaan barang/jasa pemerintah di Indonesia harus melakukan kerjasama dengan perusahaan nasional dalam bentuk kemitraan, sub kontrak dan lain-lain, dalam hal terdapat perusahaan nasional yang memiliki kemampuan dibidang yang bersangkutan. 
Ketentuan di atas merupakan beberapa sikap dari proteksionisme terhadap industri/usaha nasional sehingga menunjukan masih adanya barrier/penghalang terhadap pengusaha asing yang akan ikut serta dalam pelelangan dalam bidang pengadaan dan jasa pemerintah di Indonesia. Hal ini tentunya berbeda dengan prinsip pada GPA yang mengedepankan sikap terbuka dan non diskriminasi dalam pengadaan barang dan jasa pemerintah. Terbuka disini maksudnya dimungkinkan siapa saja dapat turut serta dalam pelelangan pengadaan barang/jasa pemerintah.

Prinsip-prinsip dari GPA ini secara prinsip dasar tidak berbeda jauh dengan prinsip yang ada pada WTO yaitu salah satunya non diskriminasi, yang artinya negara-negara WTO tidak boleh memberikan perlakuan yang berbeda dengan mitra dagangnya serta tidak boleh adanya perbedaan perlakuan antara produk/jasa lokal dengan impor atau dari luar. Hal ini dikarenakan GPA sendiri merupakan perjanjian di bawah WTO. WTO merupakan organisasi yang berdasarkan peraturan yang merupakan hasil perundingan, aturan tersebut disebut dengan perjanjian (agreements). GPA itu sendiri merupakan salah satu perjanjian plurilateral di mana perjanjian ini dilakukan antara lebih dari dua negara, tetapi tidak terlalu banyak seperti perjanjan multilateral serta perjanjian ini tidak seperti perjanjian lain seperti GATT dan GATS yang mengikat seluruh anggota WTO.

Tujuan dari WTO pada dasarnya adalah agar perputaran global dan kegiatan ekonomi, perdagangan, investasi dan bisnis dapat berlangsung tanpa banyak hambatan atau bebas hambatan. ${ }^{15}$ Tujuan ini tentunya tidak jauh berbeda dengan prinsip GPA yaitu mengedepankan sifat keterbukaan. Mengenai sikap protektif Indonesia terhadap usaha nasional memang tidak terlepas dari Rencana Pembangunan Jangka Menengah (RPJMN) 2015- 2019 di mana dijabarkan dalam Lampiran 2 Peraturan Presiden No 2 Tahun 2015 Tentang RPJMN 2015-1019 dalam Buku I Tentang Agenda Pembangunan Nasional pada bagian

\footnotetext{
15 Budi Winarno, Globalisasi: Peluang atau Ancaman Bagi Indonesia, 23 Erlangga, Jakarta, 2008.
} 
"Meminimalisasi Dampak Globalisasi" yang menyebutkan bahwa strategi yang akan ditempuh dalam meminimalisasi dampak globalisasi dalam hal perdagangan internasional salah satunya adalah mengutamakan perlindungan terhadap pasar, produk, dan konsumen domestik dalam setiap proses perundingan kerjasama ekonomi internasional.

Dalam RPJMN pun disebutkan bahwa agenda pembangunan nasional yang disusun sebagai penjabaran operasional dari nawacita salah satunya adalah meningkatkan produktifitas rakyat dan daya saing di pasar internasional. Bila melihat keduanya antara bagian "Meminimalisasi Dampak Globalisasi" dengan salah satu penjabaran operasional nawacita sebagaimana diuraikan di atas maka sekilas tercermin kekurangsiapan Indonesia dalam menghadap era globalisasi khususnya dalam perdagangan internasional di mana di satu sisi agenda pembangunan nasional adalah meningkatkan daya saing di pasar intenasional namun di sisi lain disebutkan bahwa salah satu strategi terkait dampak globalisasi adalah mengutamakan perlindungan pasar produk, dan konsumen domestik dalam setiap proses perundingan kerjasama ekonomi internasional. Melihat kedua kondisi tersebut artinya bila Indonesia ingin meningkatkat daya saing di pasar Internasional maka seharusnya sudah tidak lagi melindungi pasar, produk dan konsumen domestik karena Indonesia telah dianggap siap untuk berkancah dalam perdagangan Internasional.

Hal-hal inilah yang harus diperhatikan oleh Pemerintah pada umumnya dan Kementerian PUPR pada khususnya ketika Indonesia melakukan ratifikasi terhadap GPA, karena tidak hanya peraturan-peraturan terkait dengan pengadaan barang/jasa pemerintah serta peraturan dalam perdagangan internasional yang harus diperhatikan tetapi RPJMN 2015-2019 yang kita miliki pun harus diperhatikan agar tidak berseberangan dengan aturan-aturan main dalam perdagangan internasional.

Sesuai dengan Peraturan Presiden Nomor 2 Tahun 2015 tentang RPJMN 2015-2019 menyebutkan bahwa RPJMN 2015-2019 merupakan penjabaran dari 
visi, misi dan program Presiden hasil Pemilihan Umum tahun 2014 yang memuat strategi pembangunan nasional, kebijakan umum, program Kementerian/Lembaga dan lintas Kementerian/Lembaga, kewilayahan dan lintas kewilayahan, serta kerangka ekonomi makro yang mencakup gambaran perekonomian secara menyeluruh termasuk arah kebijakan fiskal dalam rencana kerja yang berupa kerangka regulasi dan kerangka pendanaan yang bersifat indikatif. RPJMN ini berfungsi diantaranya sebagai pedoman bagi Kementerian/Lembaga dalam menyusun Rencana Strategis Kementerian/ Lembaga, pedoman Pemerintah dalam menyusun Rencana Kerja Pemerintah. Selain itu RPJMN dapat dijadikan acuan bagi masyarakat untuk berpartisipasi dalam pelaksanaan pembangunan nasional. Sehingga RPJMN memiliki fungsi penting dalam arah pembangunan. Bila dikaitkan dengan sikap proteksionisme yang ada dalam Peraturan Presiden Nomor 54 Tahun 2010, meskipun Peraturan Presiden Nomor 54 Tahun 2010 merupakan produk pada RPJMN periode sebelumnya namun hal-hal mendasar seperti salah satunya tujuan dari Peraturan Presiden Nomor 54 Tahun 2010 tidak dirubah pada peraturan perubahannya yaitu pada Peraturan Presiden Nomor 04 Tahun 2015, artinya tujuan dari pengaturan Peraturan Presiden Nomor 04 Tahun 2015 masih ditujukan untuk mengutamakan industri/usaha nasional yang masih sejalan dengan RPJMN 20152019

Hal lainnya yang perlu dicermati oleh pemerintah pada umumnya dan Kementerian PUPR pada khususnya adalah mengenai metode pemilihan/pelelangan, di mana terdapat perbedaan metode pemilihan diantara keduanya seperti halnya perbedaan jenis (nomenklatur) metode dan makna yang ada sebagaimana yang telah diuraikan di atas. Pengaturan metode pelelangan yang diatur dalam GPA memang bersifat umum (GPA hanya memberikan batasanbatasan minimal) yang ditujukan bagi negara yang meratifikasi bila dibandingkan dengan yang terdapat dalam Peraturan Presiden Nomor 54 Tahun 2010 dan peraturan perubahannya serta Peraturan Menteri PU Nomor 07 Tahun 2011 dan 
peraturan perubahannya meskipun secara prinsip memiliki kesamaan diantara ketiganya. Hal ini ditujukan agar pengaturan dalam GPA lebih bersifat fleksibel dalam pelaksanaannya.

Hal-hal inilah yang menjadikan dasar bahwa Kementerian PUPR belum siap apabila Indonesia melakukan ratifikasi GPA meskipun GPA memiliki beberapa keuntungan dan Indonesia telah didesak untuk melakukan ratifikasi seperti diantaranya:

a. Keanggotaan GPA itu sediri dari tahun ke tahun terus meningkat yang kemungkinan besar dikarenakan pengadaan pemerintah rata-rata memberikan $15 \%$ atau lebih GDP dari suatu negara. Selain itu kegiatan GPA yang mencakup pembelian barang, jasa dan pekerjaan konstruksi nilainya mencapai U\$ 1.7 triliyun dalam setahun.

b. Dalam setiap pertemuan pada forum WTO, Asia Pacific Economic Cooperation (APEC), dan Asian European Economic Meeting (ASEM), Indonesia selalu dihadapkan kepada permintaan atau desakan untuk melakukan ratifikasi terhadap Government Procurement Agreement (GPA).

c. Indonesia sejak 2003 telah menyatakan akan meratifikasi GPA sekitar 5 (lima) sampai 7 (tujuh) tahun ke depan.

d. Indonesia hingga saat ini telah menjadi observer pada GPA

Pemerintah pada umumnya dan Kementerian PUPR pada khususnya perlu mempersiapkan diri dalam hal era globalisasi khususnya kearah ratifikasi GPA, karena begitu besarnya keuntungan yang akan diperoleh bila dilihat dari sisi ekonomi. Hal ini pun dapat menunjukan kepada dunia luar bila proses pengadaan barang dan jasa di Indonesia telah akuntabel, transparan dan mengedapankan prinsip-prinsip pemerintahan yang baik bila Indonesia nantinya meratifikasi GPA.

\section{Penutup}

Melihat uraian di atas maka dapat disimpulkan bahwa dilihat dari sisi pengaturan pengadaan barang dan jasa di lingkungan Pemerintah pada bidang konstruksi khususnya mengenai tujuan, prinsip dan metode pemilihan/pelelangan 
maka Kementerian PUPR belum siap apabila Indonesia melakukan ratifikasi GPA. Hal ini dikarenakan terdapat perbedaan tujuan pengaturan PBJ antara yang terdapat dalam Peraturan Presiden Nomor 54 Tahun 2010 dan peraturan perubahannya serta Peraturan Menteri PU Nomor 7 Tahun 2011 dan peraturan perubahannya dengan GPA. Selain itu terdapat pula perbedaan terkait dengan bentuk (nomenklatur) serta makna di dalamnya terkait metode pemilihan diantara keduanya. Berdasarkan kesimpulan tersebut apabila Indonesia akan melakukan ratifikasi GPA maka Pemerintah dan Kementerian PUPR pada khususnya perlu untuk melakukan penyesuaian terhadap tujuan dari pengaturan pengadaan barang dan jasa sebagaimana yang terdapat dalam Peraturan Presiden Nomor 54 Tahun 2010 dan peraturan perubahannya yang memiliki sifat mutatis mutandis dengan Peraturan Menteri PU Nomor 07 Tahun 2011 dan peraturan perubahannya. Begitu pula halnya dengan penyesuaian terhadap bentuk-bentuk (nomenklatur) metode pemilihan dan makna atau arti di dalamnya. Penyesuaian yang ada ditujukan agar Indonesia dalam hal ini Kementerian PUPR memiliki kerangka berpikir atau persepsi yang sama dalam hal pengaturan pengadaan barang dan jasa pemerintah khususnya dalam bidang konstruksi dengan yang diatur dalam GPA.

\section{Daftar Pustaka}

\section{Buku}

Budi Winarno, Globalisasi: Peluang atau Ancaman Bagi Indonesia, Erlangga, Jakarta, 2008.

Nazarkhan Yasin, Mengenal Kontrak Konstruksi di Indonesia, PT Gramedia Pustaka Pertama, Jakarta, 2006

Sjamsul Arifin, Dian Ediana Rae, Charles PR Joseph, Kerjasama Perdagangan Internasional Peluang dan Tantangan Bagi Indonesia, PT Elex Media Komputindo, Jakarta, 2007.

Soerjono Soekanto dan Sri Mamudji, Penelitian Hukum Normatif: Suatu Tinjauan Singkat, Rajawali Pers, Jakarta, 2012 


\section{Peraturan Perundang-undangan}

Undang-Undang No 7 tahun 1994 tentang Pengesahan Agreement Establishing The World Trade Organization

Peraturan Presiden No 54 Tahun 2010 Jo Perpres 70 Tahun 2012 Jo Perpres No 04 Tahun 2015 Tentang Pengadaan Barang dan Jasa Pemerintah

Peraturan Presiden No 2 Tahun 2015 tentang Rencana Pembangunan Jangka Menengah Nasional Tahun 2015- 2019

Peraturan Menteri PU No 07 Tahun 2011 Jo Pemen PU No 07 Tahun 2014 Jo Permen PUPR No 31 Tahun 2015 Tentang Standar dan Pedoman Pengadaan Pekerjaan Konstruksi dan Jasa Konsultansi.

\section{Internet}

Agreement on Government Procurement, diakses dari

https://www.wto.org/english/tratop e/gproc e/gp gpa e.htm pada 2

Oktober 2016 pukul 08.20 WIB.

Governtment Procurement Agreement diakses dari : https://www.wto.org/english/thewto e/20y e/gpa brochure2015 e.pdf pada 2 Oktober 2016 pukul 08.21WIB.

Indra Akuntono, Ini 10 Kementerian dengan Anggaran Tertinggi Pada APBN Tahun 2016, diakses darihttp://nasional.kompas.com/read/2015/11/02/20094921/Ini.10.Kem enterian.dengan.Anggaran.Tertinggi.dalam.APBN.2016 pada pukul 19.15 WIB tanggal 2 Oktober 2016.

Kwik Kian Gie, Kebijakan Pengadaan Barang dan Jasa Instansi Pemerintah, diakses dari : http://perpustakaan.bappenas.go.id/lontar/file?file=digital/20438[_Konten_]-Konten C3229.pdf pada 2 Oktober 2016 pukul 09.15 WIB.

Yunita Amalia, KPK Sebut Korupsi Pengadaan Barang dan Jasa Paling Dominan, diakses dari https://www.merdeka.com/peristiwa/kpk-sebut-korupsibarang-dan-jasa-paling-dominan.html pada pukul 20.20 WIB tanggal 2 Oktober 2016.

Fauziah Mursid, KPK: 142 Kasus di KPK Berasal dari Pengadaan Barang, diakses dari

http://nasional.republika.co.id/berita/nasional/hukum/16/06/27/o9fkjg3 35-kpk-142-kasus-di-kpk-berasal-dari-pengadaan-barang-dan-jasa pada pukul 20.20 WIB tanggal 2 Oktober 2016. 